\title{
Combination of Cholecystectomy and Salpingooophorectomy in Keyless Abdominal Rope-lifting Surgical Technique
}

\author{
Turgut Anuk, MD, Kahraman Ülker, MD, Barlas Sülü, MD, Ürfettin Hüseyinoğlu, MD \\ Department of General Surgery, Kafkas University School of Medicine, Kars, Turkey (Drs. Anuk and Sülü). \\ Department of Obstetrics and Gynecology, Kafkas University School of Medicine, Kars, Turkey (Dr. Ülker). \\ Department of Anesthesia and Reanimation, Kafkas University School of Medicine, Kars, Turkey (Dr. Hüseyinoğlu).
}

\begin{abstract}
Introduction: During keyless abdominal rope-lifting surgery (KARS) the intra-abdominal operations are performed through the single intra-umbilical incision following the lifting of the abdominal wall by sutures loaded in the Veress cannula without using $\mathrm{CO} 2$ and trocars. However, it is unclear whether KARS is suitable for the combination of two different surgical procedures performed in the lower and upper abdominal viscera. In this paper we aimed to present the first case of the combination of cholecystectomy and salpingooophorectomy performed by using the KARS technique.

Case Report: A sixty-seven year old, gravidity 7, parity 7, postmenopausal woman was referred to our center with the symptoms of nausea, vomiting and right upper abdominal pain. Physical examination was not remarkable other than a mild right upper abdominal tenderness and a positive Murphy sign. Ultrasound examination revealed a hydropic gall bladder with micro calculi and the bile duct was dilated with a width of 11-12 $\mathrm{mm}$ and there was an image compiled with bile sludge located distal to the dilatation area. In addition, there was a septated cyst with $95 \times 65 \times 46 \mathrm{~mm}$ diameters in the left adnexal region. Cholecystectomy and salpingoophorectomy were performed through the same single incision of KARS. The woman was discharged at the $2^{\text {nd }}$ postoperative day.

Conclusion: To our knowledge, this is the first case report presenting the operative management of a gall-bladder disease and adnexal cyst by using a single incision and gasless minimal invasive surgical technique. KARS seems feasible for the combination of cholecystectomy and salpingoophorectomy.
\end{abstract}

Key Words: Cholecystectomy, Minimally invasive, Ovariectomy, Salpingectomy, Surgical procedures.

Citation Anuk T, Ülker K, Sülü B, Hüseyinoğlu Ü. Combination of cholecystectomy and salpingooophorectomy in keyless abdominal rope-lifting surgical technique. CRSLS e2014.00110. DOI: 10.4293/CRSLS.2014.00110.

Copyright (C) 2014 SLS This is an open-access article distributed under the terms of the Creative Commons Attribution-Noncommercial-ShareAlike 3.0 Unported license, which permits unrestricted noncommercial use, distribution, and reproduction in any medium, provided the original author and source are credited.

Address correspondence to: Kahraman Ülker, Department of Obstetrics and Gynecology, Kafkas Üniversitesi Tip Fakültesi, 36000, Kars, Turkey. Telephone: 0090-474-225-11-50, Fax: 0090-474-225-11-93, E-mail: kahramanulker@hotmail.com

\section{INTRODUCTION}

Keyless abdominal rope-lifting surgery (KARS) is a novel gasless, single-incision laparoscopic surgical technique used in various gynecologic operations and cholecystectomy. ${ }^{1-4}$ In KARS, the anterior abdominal wall is lifted by sutures loaded in Veress cannula and then intra-abdominal operations are performed through the single intraumbilical incision. The technique does not require the use of carbon dioxide and trocars. However, upper or lower abdominal wall is elevated partially to provide adequate operative space. Thus, it is unclear whether KARS is suitable for the combination of 2 different surgical procedures performed in lower and upper abdominal viscera.

In this paper, we aimed to present the first case of combination of cholecystectomy and salpingooophorectomy performed by using the KARS technique.

\section{CASE REPORT}

A 67-year-old, gravidity 7, parity 7, postmenopausal woman was referred to our center with the symptoms of nausea, 


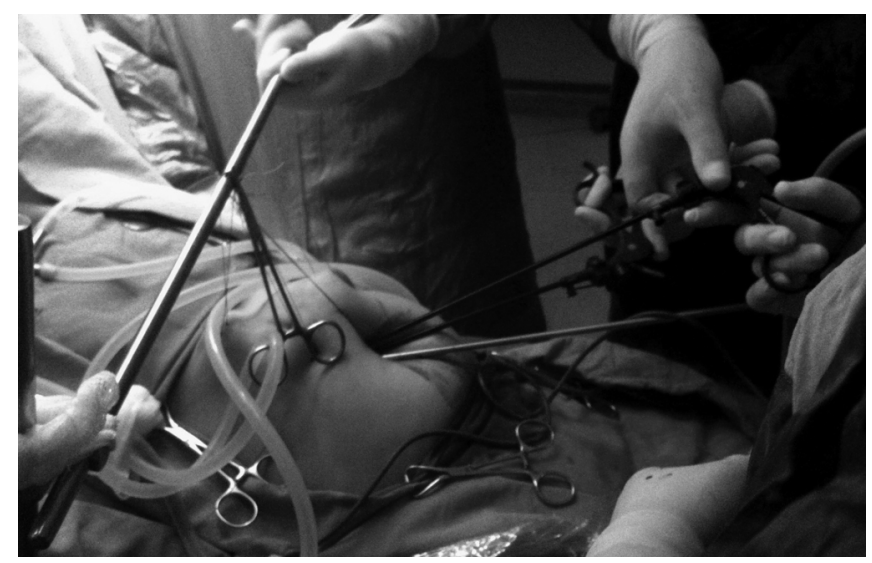

Figure 1. The abdominal wall was lifted by the ropes and the operation was performed through a single midumbilical incision by using the conventional laparoscopic hand instruments.

vomiting, and right upper abdominal pain. The symptoms had started 1 week earlier and worsened since then. Physical examination was not remarkable other than a mild right upper abdominal tenderness and a positive Murphy sign. Her medical and family histories were also unremarkable.

Ultrasound examination revealed a hydropic gall bladder with micro calculi. The wall thickness of the bladder was within normal ranges. However, the bile duct was dilated with a width of 11 to $12 \mathrm{~mm}$ and there was an image compiled with bile sludge located distal to the dilated area. In addition, there was a septated cyst with $95 \times 65 \times$ $46 \mathrm{~mm}$ diameters in the left adnexal region. Tumor markers and Doppler ultrasonographic study performed for the evaluation of the cyst were unremarkable. Thus, we planned to perform cholecystectomy and salpingooophorectomy at the same session.

One day before the operation, the bowel was prepared by using a mixture of $2.4 \mathrm{~g} / 5 \mathrm{~mL}$ monobasic sodium phosphate and $0.9 \mathrm{~g} / 5 \mathrm{~mL}$ bibasic sodium phosphate twice daily. The mixture of the 2 substances was provided at a dose of $45 \mathrm{~mL}$.

The length, weight, and body mass index of the woman were $159 \mathrm{~cm}, 67 \mathrm{~kg}$, and $26.5 \mathrm{~kg} / \mathrm{m}^{2}$, respectively. The operative technique included the previously defined 1.5to $2-\mathrm{cm}$ midumbilical transverse incision, fixation and elevation of the entry site fascia with 2 stitches, elevation of the anterior abdominal wall by sutures loaded in the Veress cannula, and tying of the sutures over the preprepared sterile retractor. However, contrary to the previously defined gynecological operations, the first ends of the lifting sutures passed the abdominal wall from inside

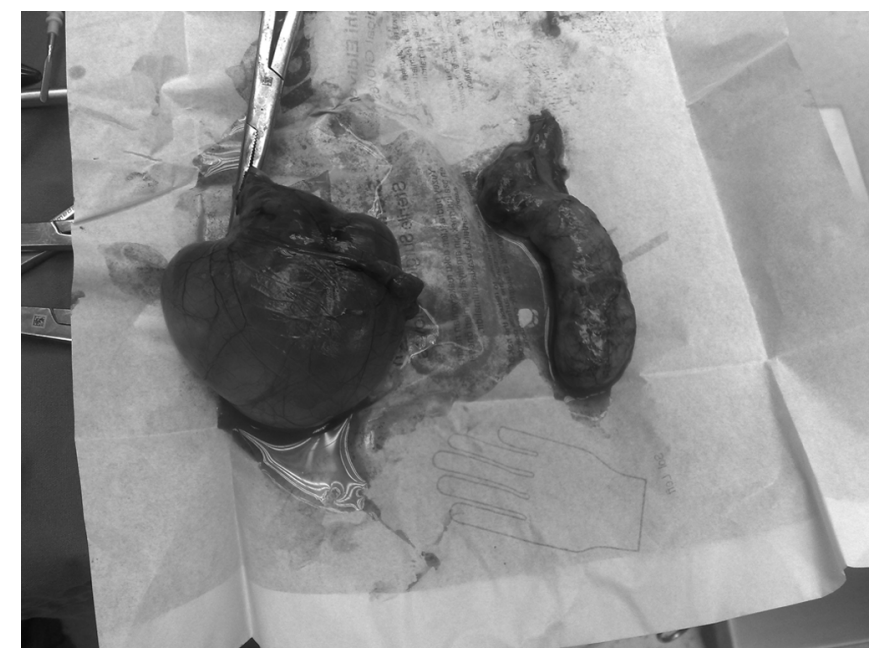

Figure 2. The retrieved tissues (cystic ovary on the left and hydropic gall bladder on the right) following cholecystectomy and salpingooophorectomy through the same midumbilical incision.

toward the outside $5 \mathrm{~cm}$ laterally at the level of umbilical fold. The second ends of the sutures passed at the level $5 \mathrm{~cm}$ above the first ends (Figure 1).

First, we performed the cholecystectomy by using the laparoscopic hand instruments without their trocars and then the salpingooophorectomy through the same single incision. The patient was maintained at head-up and head-down positions during cholecystectomy and salpingooophorectomy, respectively. Our preoperative plan was to change the location of the lifting sutures to the subumbilical area during salpingooophorectomy in order to elevate abdominal wall at the pelvic region; however, because we could easily visualize the cyst, we performed the salpingooophorectomy without changing the position of the lifting sutures.

Operative times from the beginning of the first incision to the end of the cholecystectomy and from the beginning of salpingooophorectomy to the end of wound closure were 43 and 19 minutes, respectively. The cyst and the gall bladder were easily retrieved without any laceration or rupture (Figure 2). During the retrieval of the cyst, we used a syringe to aspirate some of its fluid content to decrease its volume to fit with the diameter of the incision.

Postoperative pain scores were recorded by using the visual analogue scale as $6,3,2$, and 2 at the immediate postoperative period, postoperative $2 \mathrm{nd}$, 4th, and 24th hours. The patient did not experience shoulder pain. Simple analgesics were adequate for postoperative pain man- 
agement and the symptoms disappeared the next day. The woman was discharged on the second postoperative day. Finally, the pathological examination confirmed the preoperative diagnosis of cholecystitis and serous ovarian cyst.

\section{DISCUSSION}

To our knowledge, this is the first case report presenting the operative management of a gall bladder disease and adnexal cyst by using a single incision and a gasless, minimally invasive surgical technique.

A previous review concluded that to combine gynecological surgical procedures with cholecystectomy was appropriate when indicated and the approach eliminated a significant postoperative complication, cholecystitis; a second general anesthetic; and future hospitalization with additional time off work and patient recovery time. 5 Similarly, Wadhwa et al, ${ }^{6}$ after analyzing the 145 combined surgical procedures performed in their center, concluded that minimal access surgery was feasible and had several advantages in the simultaneous management of 2 different coexisting pathologies without significant addition in postoperative morbidity and hospital stay.

The medical literature has only a few case reports that compare different minimal access surgical techniques in combined surgical procedures. Mostly, they consist of case reports that include the combination of gynecological procedures with cholecystectomies. ${ }^{7,8}$

Although, they had to add an extra port in 1 case and make an additional incision in another case, in their recent presentation of 5 cases of double surgical procedures by using single port endo-laparoscopic surgery, Kim et al. ${ }^{9}$ concluded that the combination of procedures reduced the number of scars and could potentially reduce the number of admissions and anesthesia risks. Thus, in elective conditions, combination of multiple surgical techniques seems beneficial for the patient and is more costeffective.

The previous publications dealing with the combination of surgical procedures either used multiple access ports or had to add another port or incision. In addition, they all used carbon dioxide to create pneumoperitoneum and performed the operations under conditions with an elevated intra-abdominal pressure. During KARS, we performed both surgical procedures via the single transumbilical incision and did not use carbon dioxide, thus, while preserving the cosmetic superiority, we also eliminated the risks of carbon dioxide pneumoperitoneum.
During single-incision laparoscopic cholecystectomies, the surgeons usually have to place a stitch to the gall bladder and take the ends of the ropes outside the abdominal cavity to elevate the gall bladder and the liver to provide a sufficient operative field. That procedure elongates the operative time and increases the potential risk of an intra-abdominal injury with the tip of the needle. Some surgeons prefer to catch the gall bladder with a laparoscopic hand instrument and elevate it; however, one of the channels of the single incision port is spared and the number of the working channels is decreased permanently. In addition, parallel introduction of the telescope and the hand instruments causes difficulty in manipulation, sword fighting of the instruments and the telescope, and the obstruction of the operative field vision with an instrument passing in front of the telescope.

Although KARS shares some of the disadvantageous of single-incision laparoscopic surgery to a degree, because it does not depend on carbon dioxide pneumoperitoneum, trocars with valves are not needed to maintain the intra-abdominal pressure and the operative vision. Thus, use of instruments without trocars spares space for additional instruments. In some parts of the operation, we could use 4 hand instruments as well as the telescope.

In addition, during single-incision laparoscopic operations the manipulation of the instruments is dependent to the distance they share in the access port, and the use of a single port places restrictions on instrument manipulation, retraction, and limits triangulation. ${ }^{10}$ Although the access port has a degree of elasticity, our previous experiences with the use of a single access port showed that the elasticity of the port was lost particularly in obese patients with a thicker subcutaneous tissue. Thus, the freedom of movement and the triangulation of the instruments were diminished significantly. On the other hand, KARS does not use parallel channels and is less affected by the depth of the incision. The degree of the angle between the instruments is more than the angle obtained with the use of an access port. Thus, we could perform the operations without using angulated special hand instruments. However, in the previous study, the abdominal access time and total operative time increased in obese patients during KARS procedures. ${ }^{1}$

Tissue retrieval is also a troublesome procedure in most of the laparoscopic procedures. Carbon dioxide leakage during tissue retrieval may cause the loss of operative vision, and, in most instances, surgeons need to enlarge the access holes to retrieve tissues with a diam- 
eter of more than 1 to $1.5 \mathrm{~cm}$. Special endoscopic bags or bags made using surgical gloves are frequently needed. However, their manipulations are also difficult. Perforation of the bags or tissues may cause spreading of the contents into the abdominal cavity and cause complications. ${ }^{11}$ During KARS, tissue retrieval is easier than other minimal access procedures because the operative settings and the vision are not disturbed. Two different types of tissue retrieved from 2 different locations can be taken outside the abdomen from the same single incision. The easiness of the tissue retrieval may be one of the factors that allowed us to complete the 2 procedures in 62 minutes.

\section{CONCLUSIONS}

KARS seems to be safe and feasible for the combination of cholecystectomy and salpingooophorectomy. However, comparative studies including multiport, single-port carbon dioxide laparoscopy, and KARS are needed for further evaluation.

\section{References:}

1. Ülker K, Hüseyinoğlu Ü, Kiliç N. Management of benign ovarian cysts by a novel, gasless, single-incision laparoscopic technique: keyless abdominal rope-lifting surgery (KARS). Surg Endosc. 2013;27(1):189-198.

2. Ülker K, Hüseyinoğlu Ü. Comparison of tubal sterilization procedures performed by keyless abdominal rope-lifting surgery and conventional CO 2 laparoscopy: a case controlled clinical study. Scientific World J. 2013 Dec 24;2013:963615. doi: 10.1155/ 2013/963615. eCollection 2013.

3. Ülker K, Ersöz M, Hüseyinoğlu Ü. Management of a giant ovarian cyst by keyless abdominal rope-lifting surgery (KARS). Kafkas J Med Sci. doi: 10.5505.kjms.2011.21931.

4. Ülker K. Keyless abdominal rope-lifting surgery (KARS). Surgery S12 doi: 10.4172/2161-1076. S12-007

5. Stevens ML, Hubert BC, Wenzel FJ. Combined gynecologic surgical procedures and cholecystectomy. Am J Obstet Gynecol. 1984;149(3):350-354.

6. Wadhwa A, Chowbey PK, Sharma A, Khullar R, Soni V, Baijal M. Combined procedures in laparoscopic surgery. Surg Laparosc Endosc Percutan Tech. 2003;13(6):382-386.

7. Elazary R, Abu-Gazala M, Revel A, Benshushan A, Rivkind AI, Mintz Y. [Single incision laparoscopic combined cholecystectomy, bilateral salpingo-oophorectomy and omentectomy]. Harefuah. 2014;153(1):15-16, 65.

8. Hart S, Ross S, Rosemurgy A. Laparoendoscopic single-site combined cholecystectomy and hysterectomy. J Minim Invasive Gynecol 2010;17(6):798-801.

9. Kim G, Lomanto D, Lawenko MM, et al. Single-port endolaparoscopic surgery in combined abdominal procedures. Asian J Endosc Surg. 2013;6(3):209-213.

10. Cuschieri A. Single-incision laparoscopic surgery. J Minim Access Surg. 2011;7(1):3-5.

11. Loffeld RJ. The consequences of lost gallstones during laparoscopic cholecystectomy. Neth J Med. 2006;64(10):364-366. 